\title{
COMMENTS
}

\section{THE COERGED CONFESSION CASES IN SEARCH OF A RATIONALE}

The rationale of the thirty-two coerced confession cases decided since Brown 0. Mississippi ${ }^{1}$ has long perplexed both the Supreme Court and the commentators. No exception are the three coerced confession cases decided last term: Townsend $v$. Sain, ${ }^{2}$ Lynumn v. Illinois ${ }^{3}$ and Haynes v. Washington. ${ }^{4}$ In all three cases the Court reversed state convictions because they were based on confessions which the Court found to be coerced. In Townsend a confession was held coerced because given after the defendant, in great pain from narcotics withdrawal symptoms, had been given at his request a pain relieving drug which, without the knowledge of the interrogating officers, turned out to be a form of "truth serum." In Lynumn, the confession was held coerced because made in response to a statement by an arresting police officer that defendant's children would not be taken from her by relief authorities if she "cooperated."' And in Haynes, although the defendant had willingly admitted his guilt on arrest, a subsequent confession was held coerced because the defendant was told that he would not be allowed to call his wife until he "cooperated."

1297 U.S. 278 (1936). Of the thirty-three cases the state conviction was sustained in ten. In addition to the thirty-three, there are three other cases where the state conviction was reversed per curiam. A thirty-fourth is now before the court. United States ex rel. Jackson v. Denno, 309 F.2d 573 (1962), cert. granted, 371 U.S. 967 (1963).

2372 U.S. 293 (1963).

3372 U.S. 528 (1963).

4373 U.S. 503 (1963).

5372 U.S. at 307-10. The Court remanded to the district court to hold a hearing on the truth of the allegations in the petition for habeas corpus. The petitioner, who had been convicted of murder and sentenced to death in an Illinois court, was a nineteen-year-old heroin addict who had been described as "a near mental defective." The petitioner made no claim of physical coercion.

6 372 U.S. at 531. The Court reversed a state conviction for unlawful possession and sale of marijuana. The facts presented the usual pattern of arrest in a narcotics sale case. See Comment, Administration of the Affirmative Trap and the Doctrine of Entrapment: Device and Defense, 31 U. CHI. L. REV. 137, 149-59 (1963).

7373 U.S. at 509. The Court reversed a state conviction for robbery. The defendant was picked up about one-half hour after the robbery of a gasoline service station and orally admitted the robbery to police officers while en route to the police station and shortly after his arrival at the station again orally admitted the crime. The following morning the defendant again confessed and signed a written statement, although he 
The extensive secondary literature ${ }^{8}$ emphasizes two possible reasons why the Court finds it necessary to exclude coerced confessions. First, it is argued that the Court excludes the confessions because they are unreliable evidence. And second, it is argued that the Court excludes the confessions in order to deter improper police interrogation practices. An important effort to clarify the controlling principles of the coerced confession cases occurred in Mapp $v$. Ohio, ${ }^{9}$ holding inadmissible in a state proceeding evidence obtained as the result of an unconstitutional search and seizure. Mr. Justice Clark, writing for the majority, found that the coerced confession cases compelled the result reached in Mapp:

And nothing could be more certain than that when a coerced confession is involved, "the relevant rules of evidence" are overridden without regard to "the incidence of such conduct by the police," slight or frequent. Why should not the same rule apply to what is tantamount to coerced testimony by way of unconstitutional seizure of goods, papers, effects, documents, etc.? ?10 $^{10}$

Mr. Justice Harlan, dissenting, took issue with Mr. Justice Clark:

That this [right not to be convicted by means of a coerced confession] is a procedural right and that its violation occurs at the time his improperly obtained statement is admitted at trial, is manifest. For without this right all the careful safeguards erected around the giving of testimony, whether by an accused or any other witness, would become empty formalities in a procedure where the most compelling possible evidence of guilt, a confession, would have already been obtained at the unsupervised pleasure of the police.

This, and not the disciplining of the police, as with illegally seized evidence, is surely the true basis for excluding a statement of the accused which was unconstitutionally obtained.11

refused to sign a second statement. Later that same day the defendant was taken before a magistrate for a preliminary hearing. Admission of the written statement was held error.

8 See generally, articles collected in A.A.L.S., SELECTED WRITINGS ON THE LAW OF Evidence AND TRIAL 854 (1957); Ritz, Twenty-Five Years of State Criminal Confession Cases in the U.S. Supreme Court, 19 WASH. \& LEE L. REv. 35 (1962). Suggestive of the emotional responses which problems in the area of police interrogation can evoke is a recent debate. See Inbau, Public Safety v. Individual Civil Liberties: The Prosecutor's Stand, 53 J. CRIM. L., C. \& P.S. 85 (1962); Kamisar, Public Safety v. Individual Liberties: Some "Facts" and "Theories", 53 J. CRIM. L., C. \& P.S. $17 \mathrm{I}$ (1962); Inbau, More About Public Safety 7 . Individual Civil Liberties, 53 J. CRr. L., C. \& P.S. 329 (1962); Kamisar, Some Reflections on Criticizing the Court and "Policing the Police", 53 J. CRIM. L., C. \& P.S. 453 (1962).

9367 U.S. 643 (1961).

$10 \mathrm{Id}$. at 656 .

11 Id. at 685 . 
In attempting to draw support for an exclusionary rule based on the fourth amendment's search and seizure provision from the coerced confession cases grounded in the due process and self-incrimination clauses of the fifth, Mr. Justice Clark was seeking the unified principle of exclusion which has eluded the Court since Boyd v. United States. ${ }^{12}$ In that case the Court held unconstitutional a law which compelled an individual suspected of violating the customs laws to produce his business records on pain of forfeiting his goods. The Court observed that "any forcible and compulsory extortion of a man's own testimony or of his private papers to be used as evidence to convict him of crime or to forfeit his goods, is within the condemnation of ... [the Constitution]. In this regard the fourth and fifth amendments run almost into each other." 13 Although the remark may have been appropriate for the peculiar factual situation of the Boyd case, it is the thesis of this comment that efforts to provide a unified rationale for all the constitutional exclusionary rules only make for analytical confusion. Clearly, the exclusionary rule of Weeks $v$. United States ${ }^{14}$ and Mapp $v$. Ohio ${ }^{15}$ is grounded on considerations of deterrence. ${ }^{10} \mathrm{But}$ it is here argued that the controlling standard of the coerced confession cases is to be found in the image of the accusatorial, adversary trial and that the objective of the Court, as Mr. Justice Harlan suggested, is to prevent prosecutorial circumvention of trial safeguards by means of out of court interrogation. In order to argue this thesis it is first necessary to discuss the more traditional explanations for the coerced confession cases.

The "voluntariness-trustworthiness" rationale17 is based on the argu-

12116 U.S. 616 (1886). See, e.g., the effort of Mr. Justice Frankfurter in Rochin v. California, 342 U.S. 165, 173 (1952), where the Court held constitutionally inadmissible in a state criminal proceeding evidence obtained by pumping the suspect's stomach. "It would be a stultification of the responsibility which the course of constitutional history has cast upon this Court to hold that in order to convict a man the police cannot extract by force what is in his mind but can extract what is in his stomach. To attempt in this case to distinguish what lawyers call 'real evidence' from verbal evidence is to ignore the reasons for excluding coerced confessions. Use of involuntary verbal confessions in State criminal trials is constitutionally obnoxious not only because of their unreliability. They are inadmissible under the Due Process Clause even though statements contained in them may be independently established as true. Coerced confessions offend the community's sense of fair play and decency. So here, to sanction the brutal conduct which naturally enough was condemned by the court whose judgment is before us, would be to afford brutality the cloak of law."

13116 U.S. at 630.

14232 U.S. 383 (1914).

15367 U.S. 643 (1961).

16 See Mr. Justice Harlan's dissent in Mapp v. Ohio, 367 U.S. 643, 680 (1961): “For I think it entirely clear that the Weeks exclusionary rule is but a remedy which, by penalizing past official misconduct, is aimed at deterring such conduct in the future."

17 See, e.g., Inbau, Restrictions in the Law of Interrogation and Confession, 52 
ment that a confession which is involuntary should not be admitted into evidence because an accused is likely to say anything his persecutors want him to in order to stop the persecution. ${ }^{18}$ Considerations of reliability run through the cases. In Lyons $v$. Oklahoma ${ }^{19}$ it was said: "A coerced confession is offensive to basic standards of justice, not because the victim has a legal grievance against the police, but because declarations procured by torture are not premises from which a civilized forum will infer guilt."20 And in Reck v. Pate:21 "Experience however teaches that confessions born of long detention under conditions of stress, confusion, and anxiety are extremely unreliable." 22 But at times the Supreme Court has considered it necessary to repudiate unreliability as the foundation of the coerced confession exclusionary rule: "To be sure, confessions cruelly extorted may be ... untrustworthy. But the constitutional principle of excluding confessions that are not voluntary does not rest on this consideration."23

This self-contradiction does little more perhaps than expose the Court's own uncertainty. But although considerations of reliability have influenced the Court's thinking, the chief difficulty with reliability as a controlling rationale is that in many of the cases the excluded confession

Nw. U. L. Rev. 77, 78 (1957); Inbau, Legal Pitfalls to Avoid in Criminal Interrogation, 40 J. Crim. L. \& C. 211, 212 (1949); McCormick, The Scope of Privilege in the Law of Evidence, 16 TEx. L. Rev. 447, 452-53 (1938); Mueller, The Law Relating to Police Interrogation Privileges and Limitations, 52 J. CRIM. L., C. \& P.S. 2 (1961); Ritz, supra note 8 , at 43 .

18 It would seem that if the assumption of the "voluntariness-trustworthiness" rationale - that a person is likely to lie to terminate the coercion-is valid, then an unreliable confession is more likely when the coercion is physical than when it is psychological. Yet this rationale was not mentioned in those cases where the coercion was physical. Chambers v. Florida, 309 U.S. 227 (1940); Brown v. Mississippi, 297 U.S. 278 (1936). But cf. Stein v. New York, 346 U.S. 156, 182 (1953).

19322 U.S. 596 (1944).

20 Id. at 605.

21367 U.S. 433 (1961).

22 Id. at 447 (Douglas, J., concurring). See also Stein v. New York, 346 U.S. 156, 182 (1953); Malinski v. New York, 324 U.S. 401, 422 (1945) (Rutledge, J., dissenting in part). Indicative of the Court's confusion is the first case where the unreliability rationale was expressed, Lisenba v. California, 314 U.S. 219 (1941). So unsure was the Supreme Court of the reasons why it had excluded confessions in prior cases that it made the following two statements on the same page of its opinion: (I) "The aim of the rule that a confession is inadmissible unless it was voluntarily made is to exclude false evidence. Tests are invoked to determine whether the inducement to speak was such that there is a fair risk that the confession is false." (2) "The aim of the requirement of due process is not to exclude presumptively false evidence, but to prevent fundamental unfairness in the use of evidence, whether true or false." Id. at 236.

23 Rogers v. Richmond, 365 U.S. 534, 541 (1961); see also Blackburn v. Alabama, 361 U.S. 199, 206 (1960); Spano v. New York, 360 U.S. 315, 324 (1959); Payne v. Arkansas, 356 U.S. 560, 567-68 (1958); Rochin v. California, 342 U.S. 165, $172-73$ (1952); Watts v. Indiana, 338 U.S. 49,50 n.2 (1949). 
had been shown to be reliable. In some the veracity of the confession was substantiated by internal corroboration, the police checking out details of the confession and finding them accurate. ${ }^{24}$ In others the confession was substantiated by independent evidence of guilt. ${ }^{25}$

Yet in all these cases the Court still found that admission of the confession made the conviction a violation of due process. The "voluntariness-trustworthiness" rationale fails to account for these cases.

The current popular explanation for the "coerced" confession cases is that the Supreme Court is seeking to enforce constitutional standards in the interrogation of criminal suspects by depriving law enforcement officials of admissible evidence when they overstep the line.26 The argument is that the Court has developed the exclusionary rule as a means of deterring police interrogation techniques which violate basic standards

24 See, e.g., Culombe v. Connecticut, 367 U.S. 568, 615-16 (1961) (the suspect led the police to hidden guns and pointed out where a raincoat had been hidden); Gallegos v. Nebraska, 342 U.S. 55, 69 (1951) (found the corpus delicti on basis of defendant's confession); Watts v. Indiana, 338 U.S. 49, 60 (1949) (Jackson, J., concurring) ("Such corroboration consists in one case of finding a weapon where the accused has said he hid it, and in others that conditions which could only have been known to one who was implicated correspond with his story."); cf. Lyons v. Oklahoma, 322 U.S. 596, 597 (1944) (there was a prior admittedly valid confession).

25 See, e.g., Haynes v. Washington, 373 U.S. 503, 518 (1963) ("substantial independent evidence tending to demonstrate the guilt") (indeed, one of the reasons for the inadmissibility was that the confession was "unnecessary"); Lynumn v. Illinois, 372 U.S. 528, 537 (1963); Rogers v. Richmond, 365 U.S. 534, 541 (1961); Blackburn v. Alabama, 361 U.S. 199, 206 (1960) ("other evidence establishes guilt or corroborates the confession"); Spano v. New York, 360 U.S. 315, 316 (1959) (there was an eyewitness to the crime); Payne v. Arkansas, 356 U.S. 560, 567-68 (1958); Stroble v. California, 343 U.S. 181, 190 (1952); Haley v. Ohio, 332 U.S. 596, 597 (1948); Malinski v. New York, 324 U.S. 401, 404 (1945). Although exclusion of an internally corroborated confession is clearly at odds with a trustworthiness rationale, it should be noted that exclusion of a confession where there is independent evidence of guilt is not necessarily so. This results from problems of trial administration. If the prosecution were to attempt to overcome a showing that the confession had been obtained under circumstances indicating its unreliability by introducing independent evidence of the defendant's criminal acts, then the issue on admissibility would coincide with the ultimate issue in the case-the guilt of the defendant. If, on the one hand, independent proof of guilt less than proof beyond a reasonable doubt makes the confession admissible, then the confession may come in for its independent impact on the probabilities of the case. The introduction of a confession on such a showing might still be objectionable on the ground that the practical impact of a coerced confession on the trier of fact is far greater than any minimal probative value it might have. But if, on the other hand, independent proof of guilt beyond a reasonable doubt is required to make the confession admissible, then there is no reason to admit the confession.

26 See, e.g., Allen, Due Process and State Criminal Procedures: Another Look, 48 Nw. U. L. REv. 16, 23-25 (1953); Inbau, The Confession Dilemma in the United States Supreme Court, 43 ILL. L. Rev. 442, 443 (1948); Meltzer, Involuntary Confessions: The Allocation of Responsibility Between Judge and Jury, 21 U. CHI. L. REv. 317, 343-44 (1954); Way, The Supreme Court and State Coerced Confessions, 12 J. PuB. L. 53, 55 (1963). 
of fairness and decency. ${ }^{27}$ Illustrative of this approach is Spano $v$. New York ${ }^{28}$ which reversed a conviction for murder. The Court said that "the abhorrence of society to the use of involuntary confessions ... turns on the deep-rooted feeling that the police must obey the law while enforcing the law." 20

But the difficulty with the deterrence rationale is that the test of "voluntariness" is subjective. ${ }^{30}$ The question is "whether the defendant's will was overborne at the time he confessed" 31 and is to be determined upon the "totality of the circumstances." 32 Whether or not particular police conduct amounts to coercion depends upon the individual characteristics of the suspect interrogated-his "power of resistance."33 Included in the factors considered are his age, ${ }^{34}$ level of intelligence, ${ }^{35}$ amount of education, ${ }^{36}$ prior experience with the police, ${ }^{37}$ and his race. ${ }^{38}$

27 See, e.g., Inbau, Public Safety v. Individual Civil Liberties: The Prosecutor's Stand, 53 J. CrIm. L., C. \& P.S. 85 (1962); King, Developing a Future Constitutional Standard for Confessions, 8 WAYNE L. REv. 480, 489 (1962); Maguire, "Involuntary" Confessions, 31 TuL. L. Rev. 125, 167 (1956); Mueller, supra note 17.

28360 U.S. 315 (1959).

$29 \mathrm{Id}$. at 320. See also Rogers v. Richmond, 365 U.S. 534 (1961); Blackburn v. Alabama, 361 U.S. 199 (1960); Thomas v. Arizona, 356 U.S. 390 (1958); Haley v. Ohio, 332 U.S. 596 (1948); White v. Texas, 310 U.S. 530 (1940). But cf. Gallegos v. Nebraska, 342 U.S. 55, 70 (1951) (Jackson, J., concurring).

30 See generally, Comment, Federal Constitutional Limitations on the Use of Coerced Confessions in the State Courts, 50 J. Crim. L., C. \& P.S. 265 (1959); Comment, Justice Black-Inherent Coercion: An Analytical Study of the Standard for Determining the Voluntariness of a Confession, 10 AM. U. L. REv. 53 (1961). However, there are some writers who suggest that the Court is really using an objective test. See, e.g., Mueller, supra note 17; Ritz, supra note 8 , at 43 . The basis for this position seems to be the occasional use of the phrase "inherently coercive" by the Court. See, e.g., Reck v. Pate, 367 U.S. 433, 442 (1961); Ashcraft v. Tennessee, 322 U.S. 143, 154 (1944).

31 See, e.g., Haynes v. Washington, 373 U.S. 503, 513 (1963); Lynumn v. Illinois, 372 U.S. 528, 534 (1963); Culombe v. Connecticut, 367 U.S. 568, 602 (1961); Leyra v. Denno, 347 U.S. 556, 558 (1954); Watts v. Indiana, 338 U.S. 49, 53 (1949); Chambers v. Florida, 309 U.S. 227, 240 (1940).

32 See, e.g., Haynes v. Washington, 373 U.S. 503, 513 (1963); Culombe v. Connecticut, 367 U.S. 568, 601-02 (1961); Reck v. Pate, 367 U.S. 433, 442 (1961); Payne v. Arkansas, 356 U.S. 560, 567 (1958); Fikes v. Alabama, 352 U.S. 191, 197 (1957).

33 See, e.g., Haynes v. Washington, 373 U.S. 503, 513 (1963); Lynumn v. Illinois, 372 U.S. 528, 534 (1963); Culombe v. Connecticut, 367 U.S. 568, 602 (1961); Thomas v. Arizona, 356 U.S. 390, 393 (1958); Fikes v. Alabama, 352 U.S. 191, 197-98 (1957).

34 See Gallegos v. Colorado, 370 U.S. 49 (1962); Haley v. Ohio, 332 U.S. 596 (1948); cf. Reck v. Pate, 367 U.S. 433 (1961); Lee v. Mississippi, 332 U.S. 742 (1948).

35 See Culombe v. Connecticut, 367 U.S. 568 (1961); Reck v. Pate, 367 U.S. 433 (1961); Blackburn v. Alabama, 361 U.S. 199 (1960); Payne v. Arkansas, 356 U.S. 560 (1958); Fikes v. Alabama, 352 U.S. 191 (1957).

36 See Crooker v. California, 357 U.S. 433 (1958); Payne v. Arkansas, 356 U.S. 560 (1958); Fikes v. Alabama, 352 U.S. 191 (1957); Gallegos v. Nebraska, 342 U.S. 55 (1951). But cf. Ashcraft v. Tennessee, 322 U.S. 143 (1944).

37 See Haynes v. Washington, 373 U.S. 503 (1963); Lynumn v. Illinois, 372 U.S. 528 
These cumulative factors which determine the resistance of the suspect are then weighed against the "pressure" exerted by the interrogators. ${ }^{39}$ Among the factors which have been held to constitute police pressure are physical brutality, ${ }^{40}$ depriving the suspect of sleep ${ }^{41}$ or food, 42 protracted periods of questioning, ${ }^{43}$ threats ${ }^{44}$ and holding the suspect incommunicado for a long period. 45 If the pressure was greater than the power of resistance, the confession is considered "involuntary." What constitutes coercion for one accused will not do so for another because it takes greater pressure to overbear the "power of resistance" of one individual than another.

If the purpose of excluding coerced confessions is to deter the police from violating the rights of the accused in interrogation, then one would expect that those rights would be the same for all citizens. But instead these "rights" shift from citizen to citizen. ${ }^{46}$ Such a shifting standard is

(1963); Reck v. Pate, 367 U.S. 433 (1961); Spano v. New York, 360 U.S. 315 (1959); cf. Malinski v. New York, 324 U.S. 401 (1945).

38 See Blackburn v. Alabama, 361 U.S. 199 (1960); Payne v. Arkansas, 356 U.S. 560 (1958); Thomas v. Arizona, 356 U.S. 390 (1958); Fikes v. Alabama, 352 U.S. 191 (1957); Gallegos v. Nebraska, 342 U.S. 55 (1951); Lee v. Mississippi, 332 U.S. 742 (1948); Haley v. Ohio, 332 U.S. 596 (1948); White v. Texas, 310 U.S. 530 (1940); Chambers v. Florida, 309 U.S. 227 (1940); Brown v. Mississippi, 297 U.S. 278 (1936).

39 See, e.g., Lynumn v. Illinois, 372 U.S. 528, 534 (1963); Rogers v. Richmond, 365 U.S. 534, 540-41 (1961); Spano v. New York, 360 U.S. 315 (1959); Thomas v. Arizona, 356 U.S. 390, 393 (1958); Fikes v. Alabama, 352 U.S. 191, 198 (1957); Harris v. South Carolina, 338 U.S. 68, 71 (1949); Lyons v. Oklahoma, 322 U.S. 596, 602 (1944).

40 Brown v. Mississippi, 297 U.S. 278 (1936).

41 Lisenba v. California, 314 U.S. 219 (194I); Chambers v. Florida, 309 U.S. 227 (1940).

42 Payne v. Arkansas, 356 U.S. 560 (1958).

43 Spano v. New York, 360 U.S. 315 (1959); Leyra v. Denno, 347 U.S. 556 (1954); Harris v. South Carolina, 338 U.S. 68 (1949); Watts v. Indiana, 338 U.S. 49 (1949); Ashcraft v. Tennessee, 322 U.S. 143 (1944).

44 Haynes v. Washington, 373 U.S. 503 (1963); Lynumn v. Illinois, 372 U.S. 528 (1963); Rogers v. Richmond, 365 U.S. 534 (1961).

45 Culombe v. Connecticut, 367 U.S. 568 (1961); Reck v. Pate, 367 U.S. 433 (1961); Fikes v. Alabama, 352 U.S. 191 (1957); Turner v. Pennsylvania, 338 U.S. 62 (1949).

46 One of the unresolved questions in the coerced confession cases is whether there is any constitutional violation absent the introduction of the confession into evidence. In Williams v. United States, 341 U.S. 97 (1951) the Court upheld a conviction under the civil rights act for biutal treatment of a prisoner during interrogation. The reasoning of the Court suggested that the defendants deprived the prisoner of his constitutional rights because any confession obtained would have been coerced. "It is as plain as a pikestaff that the present confessions would not be allowed in evidence whatever the school of thought concerning the scope and meaning of the Due Process Clause." Id. at 101. But in Townsend v. Burke, 334 U.S. 736 (1948), the Court rejected the contention that the extraction of a confession not introduced into evidence made the conviction a violation of due process. "Petitioner also relies on Haley v. Ohio, 332 U.S. 596, in which this Court reversed a state court murder conviction because it was ... [coerced]. Even aside from the differing facts, that case provides no pre- 
not compatible with objectives of deterrence. As the law now stands the police have little to lose from interrogation. They can apply increasingly greater pressure until the suspect confesses. If the confession is admissible, well and good. If it is not, no harm has been done since the police wouldn't have been able to get the confession unless they had applied the pressure. ${ }^{47}$ Thus the Court's approach to a determination of coercion is incompatible with a deterrence rationale. ${ }^{48}$

The most satisfactory statement of the rationale of the Supreme Court in holding "coerced" confessions inadmissible under the fourteenth amendment is that the exclusionary rule is necessary to prevent state law enforcement authorities from circumventing the safeguards of the accusatorial, adversary trial. For example, the effectiveness of the defendant's right to counsel ${ }^{49}$ would be sharply reduced if the prosecutor could obtain a conviction based on a confession extracted from an accused held incommunicado. Two non-controversial assumptions made by the Court lie behind this reasoning. First that the goal of our system of criminal justice is to protect the innocent and convict the guilty, and that this goal is best achieved by means of the accusatorial, 50 adversary trial. Second, that the introduction of a confession into evidence has a powerful impact on the trier of fact, substantially increasing the probabilities of conviction. ${ }^{51}$ The Court's acceptance of this second assumption is shown by the automatic reversal rule-the admission of a coerced confession can never be, in the Court's view, non-prejudicial.52

cedent for relief to this prisoner since, as has been said, no confession was used against him ...." Id. at 738.

47 An analogous point can be based on the fact that several cases indicate that the intent of the law-enforcement authorities is not a factor in considering whether there was coercion and whether the confession is admissible. See Townsend v. Sain, 372 U.S. 293, 308 (1963); Blackburn v. Alabama, 361 U.S. 199 (1960); Stroble v. California, 343 U.S. 181, 190 (1952). But see contra, Ashdown v. Utah, 357 U.S. 426, 431 (1958). Although problems of proof and a desire to make the police more careful might well make extension of a deterrent exclusionary rule to unintentional conduct logical, the distinction between intentional and unintentional police conduct would seem worthy of consideration if the Court is in fact using a deterrence rationale.

48 Cf. Ashcraft v. Tennessee, 322 U.S. 143, 158 (1944), where Mr. Justice Jackson, dissenting, disclaimed the deterrence rationale. "We have no power to discipline the police or law-enforcement officers ... nor to reverse ... [state] convictions in retribution for conduct which we may personally disapprove."

49 See Gideon v. Wainwright, 372 U.S. 335 (1963); Powell v. Alabama, 287 U.S. 45 (1932).

50 The cases often contrast the accusatorial trial with an inquisitorial system. See, e.g., Gallegos v. Colorado, 370 U.S. 49, 50-51 (1962); Reck v. Pate, 367 U.S. 433, 446 (1961) (Douglas, J., concurring); Rogers v. Richmond, 365 U.S. 534, 540-41 (1961); Blackburn v. Alabama, 361 U.S. 199, 206-07 (1960); Watts v. Indiana, 338 U.S. 49, 54 (1949); cf. White v. Texas, 310 U.S. 530, 533 (1940); Chambers v. Florida, 309 U.S. 227, 239 (1940).

51 See Meltzer, supra note 26, at 326-27.

52 The automatic reversal rule states that a conviction will be reversed if an in- 
Brown v. Mississippi ${ }^{53}$ demonstrates that the novelty of the foregoing statement is only in its articulation. There the Court said that "a wrong so fundamental [had been committed] that it made the whole proceeding a mere pretense of a trial and rendered the conviction and sentence wholly void." 54 In other cases the Court has specifically adverted to the standard of permissible trial conduct as the test of coercion. Lisenba $v$. California, ${ }^{55}$ although it resulted in an affirmance of the state conviction, gives one of the clearest indications that the Court is measuring the circumstances under which the confession is obtained against what can be done at the trial: "To extort testimony from a defendant by physical torture in the very presence of the trial tribunal is not due process. The case stands no better if torture induces an extra-judicial confession which is used as evidence in the courtroom."56 An equally explicit comparison with the trial was made in Ashcraft $v$. Tennessee ${ }^{57}$ which reversed a murder conviction:

voluntary confession has been admitted into evidence, regardless of any other and independent evidence of guilt. Generally the reason for this rule is said to be that because of the general verdict, there is no way to determine whether or not the jury relied upon the confession in its guilty verdict. See, Lynumn v. Illinois, 372 U.S. 528, 537 (1963); Payne v. Arkansas, 356 U.S. 560, 568 (1958); Lyons v. Oklahoma, 322 U.S. 596, 597 n.I (1944). Contra, Stein v. New York, 346 U.S. 156, 190 (1953).

53297 U.S. 278 (1936).

54 Id. at 286. But see Ritz, Twenty-Five Years of State Criminal Confession Cases in the U.S. Supreme Court, 19 WASH. \& LEE L. REv. 35, 43-45 (1962), reading Brown v. Mississippi, 297 U.S. 278 (1936), as excluding the confession because "confessions obtained by physical torture are so inherently untrustworthy as evidence . . .."

In view of the extreme circumstances under which the confessions were obtained, the Court probably did not consider it necessary to develop any single rationale. Rather the whole proceeding was held to be void since the methods used were "revolting to the sense of justice." Id. at 286. Other cases hint at this visceral reaction test of due process. Chambers v. Florida, 309 U.S. 227, 241 (1940) (" $[N]$ o such practice as that disclosed by this record shall send any accused to his death."); White v. Texas, 310 U.S. 530, 533 (1940). In Rochin v. California, 342 U.S. 165 (1952) the Court reversed a state conviction for possession of morphine. Although there was no confession in the usual sense, the evidence obtained by emptying the defendant's stomach was held inadmissible since it was obtained by "conduct that shocks the conscience." Id. at 172. 55 314 U.S. 219 (1941).

56 Id. at 237. The Court continued: "A trial dominated by mob violence in the courtroom is not such as due process demands. The case can stand no better if mob violence anterior to the trial is the inducing cause of the defendant's alleged confession.

"If, by fraud, collusion, trickery, and subordination or perjury, on the part of those representing the State, the trial of an accused person results in his conviction, he has been denied due process of law. The case can stand no better if, by the same devices, a confession is procured, and used in the trial.

"The concept of due process would void a trial in which, by threats or promises in the presence of court and jury, a defendant was induced to testify against himself. The case can stand no better if, by resort to the same means, the defendant is induced to confess and his confession is given in evidence." Ibid.

57322 U.S. 143 (1944). 
It is inconceivable that any court of justice in the land, conducted as our courts are, open to the public, would permit prosecutors serving in relays to keep a defendant witness under continuous cross-examination for thirty-six hours without rest or sleep in an effort to extract a "voluntary" confession. Nor can we, consistently with Constitutional due process of law, hold voluntary a confession where prosecutors do the same thing away from the restraining influences of a public trial in an open court room. ${ }^{58}$

Beyond these explicit references to the trial there is equally strong support for the theory that the Court is imposing the image of the adversary trial on the interrogation process in the emphasis of the cases on the need for equality between the interrogators and the suspect. Through the right to counsel, the adversary system seeks to guarantee the equality of the adversaries. ${ }^{59}$ Counsel are presumed equal. But if this equality is to be guaranteed in the absence of counsel at interrogation, then the accused's ability to protect his own interests becomes relevant. In Gallegos $v$. Colorado ${ }^{60}$ the conviction of a fourteen year old boy for first degree murder was reversed principally because for a five day period "he was cut off from contact with any lawyer or adult advisor ...." 61 At no time did the majority opinion refer to the confession as "involuntary" or "coerced," rather it said: "[W]e deal with a person who is not equal to the police in knowledge and understanding of the consequences of the questions and answers being recorded and who is unable to know how to protect his own interests or how to get the benefits of his constitutional rights. . . Adult advice would have put him on a less unequal footing with his interrogators." 62 The confession was inadmissible because obtained where there was no equality between the adver-

58 Id. at 154. In Malinski v. New York, 324 U.S. 401, 410 (1945), a conviction for murder was reversed because a confession was admitted into evidence and "coerced confessions would find a way of corrupting the trial . ..." And in Chambers v. Florida, 309 U.S. 227, 236 (1940), the Court reversed the conviction because "due process ... was intended ... to protect, at all times, people charged with or suspected of crime by those holding positions of power and authority." From the fact that the Court found procedural due process was intended to protect "at all times" it can be argued that the court intended to give the same protection at all timesbefore as well as during the trial.

59 Gideon v. Wainwright, 372 U.S. 335,344 (1963): "From the very beginning, our state and national constitutions and laws have laid great emphasis on procedural and substantive safeguards designed to assure fair trials before impartial tribunals in which every defendant stands equal before the law. This noble ideal cannot be realized if the poor man charged with crime has to face his accusers without a lawyer to assist him."

60370 U.S. 49 (1962).

61 Id. at 54 .

62 Ibid. 
saries. ${ }^{63}$ Also demonstrative are the cases where the dominant image is of the "terrible engine of the criminal law" on the one hand, and the lonely, uneducated "individuals who stand helpless before it" on the other. ${ }^{64}$ In Lynumn, the sole basis for holding the confession inadmissible was that the police had told the suspect that her children wouldn't be taken from her if she cooperated "while she was encircled in her apartment by three police officers and a twice convicted felon who had purportedly 'set her up.' There was no friend or advisor to whom she might turn. She had had no previous experience with the criminal law, and had no reason not to believe that the police had ample power to carry out their threats." 65 And in Haynes, notwithstanding the defendant's "prior contacts with the authorities," the Court found that "he had "no reason not to believe that the police had ample power to carry out their threats" " and that he could call his wife only if he "cooperated." 66 On the other hand, in Lisenba \%. California ${ }^{67}$ where the defendant was questioned for a protracted period, slapped by a police officer and subjected to other illegal police conduct the Court held the confession to be uncoerced. The defendant was "a man of intelligence and business experience" 68 and "exhibited a self-possession, a coolness, and an acumen throughout his questioning, and at his trial . . . "60 Where there is sharp deviation from the ideal of adversary equality because the suspect is young, ${ }^{70}$ naive as to the working of the criminal law, ${ }^{71}$ or of low mentality, ${ }^{72}$ the Court makes it impossible for the law enforcement authorities to utilize their advantage by holding the confession inadmissible.

63 Compare Haley v. Ohio, 332 U.S. 596 (1948), relied on in Gallegos. There the defendant was a 15 year old negro, was questioned for 5 hours in the early morning hours by relays of policemen, while his lawyer was refused admission to see him. "[W]e cannot believe that a lad of tender years is a match for the police in such a contest. He needs counsel and support if he is not to become the victim first of fear, then of panic. He needs someone on whom to lean lest the overpowering presence of the law, as he knows it, crush him." Id. at 599-600.

64 Culombe v. Connecticut, 367 U.S. 568, 575 (1961).

B5 Lynumn v. Illinois, 372 U.S. 528, 534 (1963).

66 Haynes v. Washington, 373 U.S. 503, 514 (1963).

67314 U.S. 219, 228-41 (1941).

$68 \mathrm{Id}$. at 229.

$69 \mathrm{Id}$. at 241. See also Crooker v. California, 357 U.S. 433 (1958), where the Court first rejected the facts of police detention, of an admonition to tell the truth and of a failure of prompt arraignment as sufficient to render the confession involuntary, and then found that the denial of the defendant's request for counsel did not constitute coercion. "It [a finding of coercion] is negated here by petitioner's age, intelligence, and education. Thile in law school he had studied criminal law; indeed, when asked to take the lie detector test, he informed the operator that the results of such a test would not be admissible at trial absent a stipulation by the parties." Id. at 438 .

70 See cases cited note 34 supra.

71 See cases cited note 37 supra.

72 See cases cited note 35 supra. 
The adversary equality theory results in the subjective test of involuntariness. The amount of pressure that the police can apply and the devices that they may use in interrogating depend upon the ability of the accused to withstand pressure. The subjective test is an equalizing device-the weaker the suspect, the more restricted are the police. ${ }^{73}$

The adversary equality theory is further illustrated by Crooker $v$. Califormia ${ }^{74}$ holding that the defendant had no right to counsel at interrogation. In Crooker Mr. Justice Clark observed that a "state refusal of a request to engage counsel violates due process ... . if he is deprived of counsel for any part of the pretrial proceedings, provided that he is so prejudiced thereby as to infect his subsequent trial with an absence of 'that fundamental fairness essential to the very concept of justice." "75 Mr. Justice Clark went on to find that Crooker had no right to counsel because "the sum total of the circumstances here during the time petitioner was without counsel is a voluntary confession by a college-educated man with law school training who knew of his right to keep silent."76 This appears to mean that the very factors which make a confession voluntary also eliminate the right to counsel, that only when a confession is coerced does one have a right to counsel at interrogation. But if the confession is coerced it is inadmissible, and one has no need for counsel. The right to counsel in Crooker is really part and parcel of the emphasis on equality in the coerced confession cases. As long as one is a match for his interrogators, he has no need for counsel. But if the accused is unequal to his interrogators, then counsel is needed to right the balance. ${ }^{77}$ As a practical matter Crooker holds that there is no right to counsel at interrogation. But it does so in a fashion which is in accord with the accusatorial rationale for the coerced confession cases.

The Court's use of the image of the trial is also illustrated by the emphasis placed on the failure of prompt arraignment as a factor pointing to the existence of "coercion."78 The Court has held that there is no

73 See text accompanying notes 30-48 supra for a discussion of the subjective test. 74357 U.S. 433 (1958).

75 Id. at 439.

76 Id. at 440.

77 The absence of counsel or friends during interrogation is often emphasized in the coerced confession cases. See, e.g., Haynes v. Washington, 373 U.S. 503, 514 (1963); Lynumn v. Illinois, 372 U.S. 528, 534 (1963); Gallegos v. Colorado, 370 U.S. 49, 55 (1962); Culombe v. Connecticut, 367 U.S. 568, 632-33 (1961); Reck v. Pate, 367 U.S. 433, 441 (1961); Payne v. Arkansas, 356 U.S. 560, 563 (1958); Fikes v. Alabama, 352 U.S. 191, 196-97 (1957); Leyra v. Denno, 347 U.S. 556, 561 (1954); Haley v. Ohio, 332 U.S. 596, 600-01 (1948).

78 See, e.g., Haynes v. Washington, 373 U.S. 503, 514 (1963); Gallegos v. Colorado, 370 U.S. 49, 55 (1962); Culombe v. Connecticut, 367 U.S. 568, 631-32 (1961); Payne v. Arkansas, 356 U.S. 560, 563 (1958); Fikes v. Alabama, 352 U.S. 191, 196-97 (1957); 
fourteenth amendment right to prompt arraignment ${ }^{79}$-but continues to rely on prolonged detention as significant in the "coerced" confession cases. Such a reliance flows naturally from the adversary theory. The longer the police have to conduct an incommunicado interrogation the greater their advantages over the suspect. At arraignment, however, the suspect is advised of his rights, putting him in a better position to exercise them.

The rationale here urged as the one which best accounts for all the elements of the coerced confession cases may be summarized as follows. The accusatorial, adversary trial is the most effective means of accomplishing the goals of the system. When a confession is admitted into evidence it has such a persuasive effect upon the trier of fact as to substantially determine the outcome of the trial. As a result the outcome of the trial is substantially predetermined at the time the confession is obtained. If the adversary theory is not maintained at that time, its benefits are lost to the defendant and to the system. Therefore the adversary theory should govern the proceeding at which the confession is obtained and no confession obtained under circumstances not incompatible with an accusatorial, adversary system should be admitted into evidence.

The accusatorial rationale is not, of course, incompatible with considerations either of reliability or deterrence. To the extent that confessions which are involuntary are unreliable, reliability is furthered. And to the extent that the police strive to obtain admissible confessions, police excesses are deterred. But the central focus of the coerced confession cases is not on reliability or on controlling police conduct. It is on procedural fairness in the particular case before the Court. It would be a strange way of speaking to say that appellate courts reverse trial courts to deter future errors by the trial judge. Rather, an appellate court reverses a trial court to ensure that the particular defendant in the case before the court has been accorded equal treatment before the law. But it cannot be denied that appellate reversals also have the effect of deterring similar future conduct by trial judges. The difficulty with the trustworthiness and deterrence rationales is not that they raise considerations which are inapposite, but that they fail to account satisfactorily for all of the cases.

The real problem of the coerced confession cases is not their theoreti-

Watts v. Indiana, 338 U.S. 49,54 (1949); Turner v. Pennsylvania, 338 U.S. 62, 63-64 (1949); Harris v. South Carolina, 338 U.S. 68, $69-70$ (1949).

79 Culombe v. Connecticut, 367 U.S. 568, 600-01 (1961) (Frankfurter, J.); Stein v. New York, 346 U.S. 156, $187-88$ (1953); Brown v. Allen, 344 U.S. 443, 476 (1953); Stroble v. California, 343 U.S. 181, 197 (1952); cf. Lyons v. Oklahoma, 322 U.S. 596 597 n.2 (1944). 
cal basis but their administration. A test involving so many different factors and such difficult evaluations is inherently impossible of even application. It would be a logical extension of the accusatorial rationale to hold that a confession not delivered in open court is not admissible into evidence. This, however, the Court has reasonably declined to do on the ground that interrogation, of itself, does not unduly undermine the procedural safeguards of the trial. But as long as some confessions are admissible, then distinctions must be drawn in each case. The Court could make the drawing of these distinctions a simpler matter if it were to transmute the elements of police conduct which the Court now considers relevant to a determination of subjective involuntariness into objective prerequisites to admissibility. The $M c N a b b$ rule is a step in this direction by the federal courts in considering the effect of prolonged detention..$^{80} \mathrm{~A}$ similar rule might hold that where a confession is obtained without counsel present it is inadmissible. ${ }^{81}$ But if each of the elements leading to a finding of coercion were transmuted into objective prerequisites of admissibility, then the purpose would shift from one of ensuring procedural safeguards to one of deterrence. A confession would be inadmissible in a particular case even though its admission might not jeopardize the fairness of the particular defendant's trial. Rather, the confession would be excluded because of the presence of practices so likely to go hand in hand with coercion that they must not be encouraged. The search and seizure and confession exclusionary rules would then rest on the same theoretical base. But this would be a more radical step than might at first appear. Although doubts have been expressed about the deterrent efficacy of Mapp v. Ohio, ${ }^{82}$ compliance re-

80 McNabb v. United States, 318 U.S. 332 (1943); Mallory v. United States, 354 U.S. 449 (1957). This rule holds confessions obtained from a suspect during a period of detention in violation of FED. R. CRIM. P. 5(a) inadmissible in federal criminal proceedings. A number of commentators, inspired largely by Culombe v. Connecticut, 367 U.S. 568 (1961), have suggested that the Court has already applied the $M c N a b b$ rule to the states. See Ritz, supra note 54, at 70; Comment to Article 45, Tentative Final Draft of the Proposed Illinols Code of Criminal Procedure 109 (1963); Comment, 24 GA. B.J. 120 (1961); Note, 75 Harv. L. Rev. 158 (1961); Comment, 68 YALE L.J. 1003 (1959). Two of the Justices have urged extension of the $M c N a b b$ rule to the states. Reck v. Pate, 367 U.S. 443, 448 (1961) (Douglas, J., concurring); Gallegos v. Nebraska, 342 U.S. 55, 73-75 (1951) (Black, J., dissenting).

81 Gallegos v. Colorado, 370 U.S. 49 (1962), has inspired the suggestion that such a rule already exists. See Note, 76 Harv. L. Rev. 108 (1962). Mr. Justice Douglas urges such a rule but it is unclear whether or not he would require that a request for counsel be made. Compare Culombe v. Connecticut, 367 U.S. 568, 641 (1961) ("I believe that the denial of petitioner's request that he be given the right of counsel was a violation of his constitutional rights.") (Douglas, J., concurring), with Reck v. Pate, 367 U.S. 433, 448 (1961) ("I would hold that any confession obtained by the police while the defendant is under detention is inadmissible, unless ... the accused is . . accorded an opportunity to consult counsel.") (Douglas, J., concurring).

82367 U.S. 643 (1961). See Allen, Federalism and the Fourth Amendment: A Re- 
quires only that the police obtain a warrant. A rational allocation of police resources would not call for a program of unreasonable-and hence, almost by definition, largely fruitless-searches. But in the large majority of cases a requirement of prompt arraignment and counsel would make interrogation fruitless. A pervasive characteristic of the coerced confession cases is that they involve unwitnessed crimes of violence $^{83}$ which leave little physical evidence. Yet these are the very crimes which most strongly affect the community's sense of security. If the Court chooses to foreclose the admission of confessions altogether, or to raise the requirements of prompt arraignment and counsel to rigid prerequisites of admissibility, then law enforcement officials might be unable to obtain convictions of those responsible for these crimes. In formulating constitutional rules governing the admissibility of confessions, the Court should consider that requirements which would render interrogation ineffective might immunize this class of criminals from the criminal process.

quiem for IVolf, 1961 Sup. CT. Rev. 1, 37-39. Professor Allen points out that in dealing with the type of organized, sumptuary crime which is often the target of illegal searches, the police may not desire to obtain actual convictions. "Under such circumstances, the conviction of defendants may not be the only, or even the most important, objective of police action. ... Putting aside all question of corruption or improper political pressure, the police may permit themselves policies of "prevention" and harassment, involving the range of traditional illegalities from illegal detention of persons to unauthorized destruction of property. The threat of the exclusionary rule is likely to have little potency here, for these police activities are not pursued with criminal prosecution as the end in view." $I d$. at 39.

83 The thirty-three state coerced confession cases include 25 convictions for murder, 4 for rape, 2 for robbery, 1 for manslaughter, and 1 for unlawful possession and sale of marijuana. 